Sains Malaysiana 49(9)(2020): 2053-2063

http://dx.doi.org/10.17576/jsm-2020-4909-03

\title{
Short Term Gold-Mine Tailings Exposure Induced Growth and Photosynthesis of Philippine Tung (Reutealis trisperma [Blanco])
}

(Pendedahan Amang Lombong Emas Jangka Pendek Teraruh Pertumbuhan dan Fotosintesis Philippine Tung (Reutealis trisperma $[$ Blanco]))

\author{
Hamim Hamim*, Dibyo Pranowo, Luluk Setyaningsih, Muhammad Hilmi \& Deden Saprudin
}

\begin{abstract}
Philippine Tung (Reutealis trisperma [Blanco] Airy Shaw) is one of non-edible oil producing plant resistant to unfavorable conditions and therefore this plant has prospective role to be used in phytoremediation program on gold post-mined area. The experiment aimed to analyze photosynthesis and growth of $\mathrm{R}$. trisperma plants in response to short term gold-mine tailing treatment in polybag experiment. The experiment was carried out using completely randomized design with two factors and 5 replications. The first factor was five varieties of $\mathrm{R}$. trisperma (M1, M2, D1, D2 and HR) and the second factor was gold-mine tailings treatment comprised 0, 25, 50, and 100\% of tailings which was applied in combination with mixed compost and soil 1:3 (v/v) as a basic media. Plant growth and physiological characters were observed after 6 weeks of the treatment. The result showed that even though malondialdehyde (MDA) of $\mathrm{R}$. trisperma leaves increased slightly, but the plants treated with gold-mine tailing had higher photosynthetic rate than that of the control (untreated) plants, which resulted in the improvement of root and shoot growth up to 70 and $90 \%$, respectively. Higher content of $\mathrm{Ca}, \mathrm{Mg}, \mathrm{Fe}, \mathrm{Zn}$, and $\mathrm{Mn}$ in gold-mine tailing may have positive effect to $\mathrm{R}$. trisperma indicated by photosynthesis and growth enhancement which suggests the plant tolerance to gold-mine tailings.
\end{abstract}

Keywords: Gold-mine tailing; heavy metal stress; photosynthesis; phytoremediation; Reutealis trisperma

\section{ABSTRAK}

Philippine Tung (Reutealis trisperma [Blanco] Airy Shaw) adalah salah satu daripada tumbuhan hasilan minyak yang tidak dapat dimakan yang tahan terhadap keadaan yang kurang baik dan oleh itu tumbuhan ini mempunyai peranan yang akan digunakan dalam program fitopemulihan pada kawasan pasca lombong emas. Uji kaji ini bertujuan untuk menganalisis fotosintesis dan pertumbuhan tumbuhan R. trisperma sebagai tindak balas terhadap rawatan amang emas jangka pendek dalam percubaan polibeg. Uji kaji ini dijalankan menggunakan reka Acak Lengkap dengan dua faktor dan 5 ulangan. Faktor pertama adalah lima jenis R. trisperma (M1, M2, D1, D2 dan HR) dan faktor kedua adalah rawatan amang lombong emas terdiri daripada 0, 25, 50 dan 100\% amang yang digunakan dalam gabungan dengan campuran kompos dan tanah 1: 3 (v/v) sebagai media asas. Pertumbuhan tumbuhan dan watak fisiologi diperhatikan selepas 6 minggu rawatan. Hasilnya menunjukkan bahawa walaupun kandungan malondialdehida (MDA) daun R. trisperma meningkat sedikit, namun tumbuh-tumbuhan yang dirawat dengan amang emas mempunyai kadar fotosintesis yang lebih tinggi daripada tanaman kawalan (tidak dirawat), yang mengakibatkan peningkatan akar dan pucuk pertumbuhan masing-masing sehingga 70 dan 90\%. Kandungan $\mathrm{Ca}, \mathrm{Mg}, \mathrm{Fe}$, Zn dan Mn yang lebih tinggi dalam amang lombong emas mungkin mempunyai kesan positif kepada R. trisperma yang ditunjukkan oleh fotosintesis dan peningkatan pertumbuhan yang menunjukkan toleransi tumbuhan $\mathrm{R}$. trisperma kepada amang lombong emas.

Kata kunci: Amang lombong emas; fitopemulihan; fotosintesis; Reutealis trisperm; tegasan logam berat

\section{INTRODUCTION}

Gold mining has high economic value and therefore the area with high content of gold becomes attractive for mining industry as well as artisanal and small-scale gold miner to operate mining activities which in some extent result in heavy metals contamination to the environment (Arifin et al. 2015; Muddarisna et al. 2013). Gold mining industry typically produces waste in the form of liquid wastes and solid tailings. Liquid waste usually contains cyanide with high concentration (Hamim et al. 2017a) since cyanide is often used as a solvent in the gold mining system (Korte et al. 2000), while solid tailings contain high concentration of minerals including heavy metals (Hidayati et al. 2009; Setyaningsih et al. 2017). Several types of heavy metals commonly present in high quantities in gold mine tailings including $\mathrm{Pb}, \mathrm{Hg}, \mathrm{Cd}$ and $\mathrm{Cu}$. In 
artisanal and small gold mining, the dominant heavy metal contaminants are generally mercury $(\mathrm{Hg})$ (Arifin et al. 2015; Muddarisna et al. 2013). According to the Agency for Toxic Substances and Disease Registry (ATSDR 2003) four heavy metals ( $\mathrm{As}, \mathrm{Pb}, \mathrm{Cd}$, and $\mathrm{Hg}$ ) are considered as the most toxic metals. Therefore, the effort to reduce heavy metal contaminants from gold mine industry is a big challenge to avoid environmental damage and further heavy metal uptake by human being through biological food chain.

For most plant species, heavy metals disturb various physiological and biochemical processes including photosynthesis (Sarwar et al. 2017). Many experiments found that heavy metals caused chlorosis and nutrient uptake restriction which finally reduced plant growth and yield (Popova et al. 2009; Xu et al. 2009), and for leguminous plants they reduced nitrogen fixing capacity (Guala et al. 2010). Heavy metals have also been recognized to induce ROS production which caused cell membrane damage and destruction of biomolecules and cellular organelles (Ekmekci et al. 2008), and disturbed essential groups of enzymes (Chaffai \& Koyama 2011; Choppala et al. 2014; Sarwar et al. 2010). Therefore, the presence of such contaminants in gold mining area causes damage to plants grown in that area, so that they cannot grow and reproduce well.

Phytoremediation has been recognized as cost effective method and attractive approach for remediation of metal contaminated soils in the present scenario, because plants are the primary recipients of heavy metals (Sarwar et al. 2017). Using this method, the plants which have ability to absorb and accumulate higher heavy metal may reduce heavy metal contaminant from the site through processes known as phytostabilization (Erakhrumen 2007), phytovolatalization (Ghosh \& Singh 2005), or phytoextraction (Ali et al. 2013; Seth 2012; Vamerali et al. 2010). For phytoremediation process, the plant that is tolerant to heavy metal becomes very important, because the more tolerant plant, the more metal can be accumulated with minimum adverse effects on plant health (Sarwar et al. 2017; Seth et al. 2007).

Philippine Tung (Reutealis trisperma [Blanco] Airy Shaw) that is also known as Kemiri Sunan (Indonesia) is one of non-edible oil producer plant which has higher seed production capacity and oil content (Herman et al. 2013). This tree species has deep root system with heavy canopy and resistant to environmental condition such as erosion and drought (Herman \& Pranowo 2010). This plant also resistant to unfavorable conditions including some post-mined lands such as bauxite, tin mining and cement post-mined lands (Pranowo \& Herman 2015), but it has never been investigated to grow in gold-mine land (Hamim et al. 2017a). Due to those characteristics, this plant has a good prospect to be used in phytoremediation program in gold post-mined area.
As a source of renewable energy crops in Indonesia, $R$. trisperma is among the potential species that can be cultivated by the community especially in degraded lands including post mining lands. This is in line with the policy of renewable energy provision by utilizing neglected and underutilized plants on marginal land to avoid the use of arable land required for food production. For this reason, many experiments using $R$. trisperma provenances or cultivars were carried out to find potential candidate of plant with higher tolerant to gold mining land in the future. The experiment aimed to analyze photosynthesis and growth of $R$. trisperma plants in response to short term gold-mine tailings exposure in polybag experiment.

\section{MATERIALS AND METHODS}

\section{THE ANALYSIS OF GOLD-MINE TAILINGS}

Solid tailing samples were analyzed to identify mineral components including macro-nutrients $(\mathrm{K}, \mathrm{Ca}$, and $\mathrm{Mg}$ ) and micro-nutrients ( $\mathrm{Fe}, \mathrm{Cu}, \mathrm{Zn}, \mathrm{Mn}, \mathrm{Mo}, \mathrm{B}, \mathrm{Cl}, \mathrm{Ni}, \mathrm{Co}$ ). The tailing was also analyzed to investigate heavy metal content $(\mathrm{Pb}$ and $\mathrm{Hg})$. Macro and micronutrients as well as heavy metal analyses were carried out using atomic absorption spectroscopy (AAS).

PREPARATION OF SEEDLINGS OF PHILIPPINE TUNG In this experiment, 5 varieties of Philippine Tung (Reutealis trisperma [Blanco]) were provided from Indonesian Crops and Refreshing Plant Research Institute, Parung Kuda, Sukabumi, Indonesia. Philippine Tung seedlings were prepared by germination of the seeds in the mixed media contained soil, rice husk and sawdust $(3: 1: 1)$. The seeds were grown in a seedbed with a distance of $3 \times 3 \mathrm{~cm}$, so that in a $100 \times 20 \mathrm{~cm} 2$ seedbed, there were approximately 200 seeds. The seedbed was immediately covered with organic mulch and placed in a safe open place (Herman et al. 2013). The young seedlings (one weeks old) were then transferred into polybags $(10 \times 15$ $\mathrm{cm})$ which had been filled with planting media of mixed soil, compost and sand 1:1:1 (v/v/v). The seedlings were watered every day to keep the soil moisture. The seedlings were grown for 1.5 month before they were moved to larger polybag $(20 \times 30 \mathrm{~cm})$ and treated with gold mine tailings.

EXPERIMENTS WITH GOLD-MINE TAILING TREATMENT

The experiment was designed to investigate the response of Philippine Tung to gold mine tailings. Tailings were collected from gold mine tailing dam of Aneka Tambang Ltd., Pongkor, Bogor, West Java, Indonesia. The experiments were carried out using large polybags $(20 \times 30 \mathrm{~cm})$ for approximately $8 \mathrm{~kg}$ of soil. The experiments were conducted with a Completely Randomized Design using 2 factors. The first factor was Philippine Tung varieties namely: Kemiri Minyak-1 (M1), Kemiri Minyak-2 
(M2), Kermindo-1 (D1), Kermindo-2 (D2), and Harapan provenance (HR). The second factor was tailing treatment consisted of 4 levels without tailing, $25 \%$ of tailing, $50 \%$ of tailing, and $100 \%$ of tailing. Each experimental unit was prepared 5 times as replication.

The polybags were filled with the medium consisted of $8 \mathrm{~kg}$ of mixed soil and compost with a ratio of $3: 1$ $(\mathrm{v} / \mathrm{v})$ as basic media which was combined with the tailings according to the treatments. The 1.5-month-old Philippine Tung seedlings were grown in polybags that had been prepared according to the treatment. Watering was provided every 2 days to keep all the treatment media moist enough. At the planting time, fertilizer was given with $0.6 \mathrm{~g}$ NPK $(15: 15: 15)$ per polybag.

The plants were grown for 6 weeks and observation was carried out to analyze plant morphology, anatomy, and physiology. Morphological observation was carried out for plant height, leaf number, leaf area, and root number. The analysis of root and leaf anatomy was also carried out 6 weeks after treatments to observe anatomical response the treatments. Physiological observations were made on leaf photosynthesis rate, chlorophyll content, and MDA content to see lipid peroxidation.

The observation of photosynthetic parameters was carried out using Photosynthetic Gas Exchange Analyzer LiCOR LI-6400. Observation was made on the fully expanded leaf, where each treatment had 3 replications. The measurement was made between 08.30-10.00 a.m. using LED light source under saturated light $(2000 \mu \mathrm{mol}$ $\left.\mathrm{cm}^{-2} \mathrm{~s}^{-1}\right)$ with rectangle $\left(2 \times 3 \mathrm{~cm}^{2}\right)$ chamber.

LIPID PEROXIDATION ANALYSIS (ROS ACCUMULATION) Lipid peroxidation was observed to see the formation of free radicals (Reactive Oxygen Species, ROS) within the plant tissue by measuring malondialdehyde content. Lipid peroxidation was analyzed using a method described by Ono et al. (1995) by measuring total malondialdehyde (MDA) as an end product of lipid peroxidation. The leaves $(0.2 \mathrm{~g})$ were ground in a mortar with $0.5 \mathrm{~mL}$ of $0.1 \%(\mathrm{v} / \mathrm{v})$ trichloracetic acid (TCA) on ice to prepare leaf extract. The leaf extract then was added to $3 \mathrm{~mL}$ of $1 \% \mathrm{H}_{3} \mathrm{PO}_{4}$ and $1 \mathrm{~mL}$ of $0.6 \%$ TBA dissolved in $20 \%$ TCA. The solution was incubated in the oven at $100{ }^{\circ} \mathrm{C}$ for 30 min. After cooling at room temperature, $4 \mathrm{~mL}$ of $\mathrm{n}$-butanol solution was added and centrifuged at $4200 \mathrm{rpm}$ at the temperature of $28{ }^{\circ} \mathrm{C}$ for $20 \mathrm{~min}$. The supernatant was then measured using a UV-Vis spectrophotometer at 532 $\mathrm{nm}$ and corrected for non-specific turbidity by subtracting the absorbance at $520 \mathrm{~nm}$. The concentration of MDA was obtained from its extinction coefficient $\left(\varepsilon=155 \mathrm{~L} \mathrm{mmol}^{-1}\right.$ $\mathrm{cm}^{-1}$ ) as follow:

$$
\text { Concentration of MDA }(\mathrm{mM})=(\mathrm{A} 532-\mathrm{A} 520) / 155
$$

where A532 and A520 are the absorbances at 532 and $520 \mathrm{~nm}$.

\section{STATISTICAL DATA ANALYSIS}

Statistical analysis was carried out for all the data by one-way ANOVA using SPSS 19.0 statistical software and the means were compared by Duncan's Multi Range Test (DMRT) at the $5 \%$ probability level.

\section{RESULTS AND DISCUSSION}

\section{ANALYSIS OF SOLID WASTES (TAILING) FROM GOLD MINING INDUSTRY}

The analysis of solid waste (tailings) obtained from gold mining industry Aneka Tambang Ltd. Pongkor, Bogor, Indonesia showed that tailings contained metal elements considered as essential minerals including $\mathrm{Ca}, \mathrm{Mg}, \mathrm{Fe}$, $\mathrm{Zn}, \mathrm{Mn}$, and $\mathrm{Co}$ in very high concentrations, which were different from those in liquid wastes (Table 1). The content of micro elements of $\mathrm{Cu}, \mathrm{Mo}$, and $\mathrm{B}$ was almost the same in the two kinds of wastes. The analysis also showed that heavy metal content especially $\mathrm{Pb}, \mathrm{Cd}, \mathrm{Ag}$, and $\mathrm{Hg}$ was also very high in the tailings while in the liquid waste the compounds was much lower (Table 1). On the other hand, the cyanide content in the tailings was very low compared to that in liquid waste which contained almost 13 times more (Hamim et al. 2017a). High content of heavy metals in the tailings should be a serious concern for researchers and industries so that it is handled properly and does not cause contamination of agricultural lands, because with particular treatment the heavy metal can be reduced in a certain period. Phytoremediation is a method that has been recognized be able to reduce contaminants using plants (Sarwar et al. 2017). This method is cost effective and efficient to reduce contaminant in a wider site. Identification and selection of accumulator plants that are potential for phytoremediation is very important to support the success of remediation program in gold mine lands.

Table 1 shows that the tailings provided from tailing dam of mining industry (Aneka Tambang Ltd.) still contained high degree of heavy metal dominated by $\mathrm{Pb}$ and $\mathrm{Ag}$, while the content of $\mathrm{Hg}$ was considerably low. This was different from Hidayati et al. (2009) who found that contaminated site around artisanal and public mining including rivers, ponds, and paddy field still contained mercury $(\mathrm{Hg})$ in considerably high concentration. Therefore, for industrial mining application of phytoremediation should be directed to use the plants which have capability to reduce $\mathrm{Pb}$ and $\mathrm{Ag}$. $R$. trisperma has been recognized be able to absorb $\mathrm{Pb}$ in the root as well as shoot tissues based on qualitative histochemical analysis (Hilmi et al. 2018).

In addition to high content of heavy metals, the tailings also had high concentration of other metals categorized as essential elements such as $\mathrm{Ca}, \mathrm{Mg}, \mathrm{Fe}$, $\mathrm{Mn}$, and $\mathrm{Zn}$ (Table 1). These elements in some extent are required by plant as mineral nutrition, even though for micro-elements such as Fe, Mn, and $\mathrm{Zn}$ may become toxic for plant under higher concentration (Ali et al. 2013). 
However, high content of $\mathrm{Ca}$ and $\mathrm{Mg}$ which improved soil $\mathrm{pH}$ up to 7.2 as compared to untreated media $(\mathrm{pH}=6.3)$ may cause the availability of micronutrients might be become limited (Taiz \& Zeiger 2010). This condition suggest that solid tailing may have multiple challenges for plant growth and development, because beside the damage of physical structure, gold mine tailings also contains higher essential metal elements as well as heavy metals.

TABLE 1. Mineral, heavy metals and cyanide content of tailings and liquid waste of gold mining industry Aneka Tambang Inc. Pongkor, Bogor, Indonesia (ppm)

\begin{tabular}{lcc}
\hline \multicolumn{1}{c}{ Mineral content } & Tailings & Liquid waste $^{*}$ ) \\
\hline Macro- and micronutrient & 10.957 & 22.477 \\
$\mathrm{~K}$ & 409.392 & 12.021 \\
$\mathrm{Ca}$ & 3962.711 & 1.626 \\
$\mathrm{Mg}$ & 10348.154 & 2.172 \\
$\mathrm{Fe}$ & 1.180 & 2.064 \\
$\mathrm{Cu}$ & 22.640 & 0.867 \\
$\mathrm{Zn}$ & 1791.457 & 0.078 \\
$\mathrm{Mn}$ & $<0.005$ & $<0.005$ \\
$\mathrm{Mo}$ & $<0.020$ & $<0.020$ \\
$\mathrm{~B}$ & 0.111 & 0.046 \\
$\mathrm{Ni}$ & 3.591 & $<0.005$ \\
$\mathrm{Co}$ & & $<0.004$ \\
$\mathrm{Heavy} \mathrm{Metals}$ & 93.591 & 0.003 \\
$\mathrm{~Pb}$ & 1.261 & 0.074 \\
$\mathrm{Cd}$ & 13.364 & $<0.002$ \\
$\mathrm{Ag}$ & 0.064 & 12.400 \\
$\mathrm{Hg}$ & & \\
$\mathrm{Cyanide}(\mathrm{CN})$ & 0.810 &
\end{tabular}

\section{ANALYSIS OF MALONDIALDEHYDE CONTENT}

After gold-mine tailing exposure for 6 weeks, malondialdehyde (MDA) content of $R$. trisperma leaves was measured to investigate the occurrence of oxidative stress indicated by the accumulation of reactive oxygen species (ROS) inside the plant tissues. The treatment with gold-mine tailings caused a slight increase in MDA content of the leaves which followed the curve of $\mathrm{Y}=$ $44.76 x^{2}+241.53 x+8.06\left(R^{2}=1\right)$, and the maximum increase was reached by the treatment with $100 \%$ of tailing which increased MDA content by approximately 61\% (Figure 1 ). The increased of leaves MDA content suggested that lipid peroxidation occurred in the plants as indicative of oxidative stress. However, the increase of MDA due to the treatment with solid tailings was not as large as that in the experiments with liquid waste contained higher cyanide, which caused an increase in MDA up to more than 4 times (Hamim et al. 2017a).

The increase of MDA content is a general characteristic of plant under environmental stress such as drought, temperature, salinity, and the stress due to heavy metal as well as hydrocarbon contaminants (Apel \& Hirt 2004; Hamim et al. 2017b; Hilmi et al. 2018; Savicka \& Skute 2010). Although there was an increase of leaves MDA content, but the plants did not show symptoms of stress during 6 weeks' treatment. This was different from the treatment of gold-mine wastewater that caused discoloration of leaves from green to yellowish after the treatment of wastewater for 14 days (Hamim et al. 2017a). This different response perhaps because ROS accumulation that occurred due to the treatment with solid tailings indicated by a slight increase of MDA 
content had no negative affect to the plant. This suggests that Philippine Tung plant may have a good ability to deal with the formation of ROS through physiological mechanisms, such as antioxidant mechanism (Nazar et al. 2012) or through the strong role of peroxisomes (Apel $\&$ Hirt 2004). Previous study suggested that the leaf of $R$. trisperma grown in water culture exposed with gold mine wastewater had more peroxisomes than that of the control one (Hamim et al. 2017a).

\section{ANALYSIS OF PHOTOSYNTHESIS}

The analysis of photosynthesis showed that the treatment with gold-mine tailings for 6 weeks significantly $(\mathrm{P}<0.05)$ increased net photosynthetic rate $(\mathrm{Pn})$ of all Philippine Tung varieties (Figure 2). The significant increase of Pn was demonstrated by plants received tailing treatment of 50 and $100 \%$ although in some varieties the increase of Pn began from the tailing treatment of 25\% (Figure 2). In average, the increase of tailing concentration in the media from 25 until $100 \%$ improved photosynthetic rate from $6.6 \%$ at $25 \%$ of tailing up to $17.7 \%$ at $100 \%$ of tailing as compared to control plants following the quadratic curve of $\mathrm{Y}=0.0002 \mathrm{X} 2+0.0387 \mathrm{X}+9.8279$, (R2 0.98) (Figure 3(A)). The graph also showed that the average of photosynthesis increased significantly due to the treatment of 50 and $100 \%$ of tailing (Figure 3(A)). There was a variation response among the varieties, where Kermindo 2 (D2) had the highest average of Pn, while Kemiri Minyak 1 (M1) had the lowest (Figure (3B)).

Photosynthesis is an important physiological parameter that is highly influenced by environmental stresses such as temperature, drought, salt, and heavy metal (Allakhverdiev et al. 2008; Hamim et al. 2016; Maksymiec 2007; Nazar et al. 2011). The increase of photosynthesis in response to tailing treatments may be associated with positive response of the plants to high concentrations of some macro- and micronutrients contained in the tailings including $\mathrm{Ca}, \mathrm{Mg}, \mathrm{Fe}, \mathrm{Zn}, \mathrm{Mn}$, and $\mathrm{Co}$ (Table 1). In the case of $\mathrm{Cd}$ toxicity for example, Sarwar et al. (2010) explained that the nutrient adequacy including $\mathrm{Ca}$, $\mathrm{Mg}, \mathrm{Fe}$, and $\mathrm{Zn}$ will compete with $\mathrm{Cd}$ absorption which lessening toxic effect of this metal to the plants. Nazar et al. (2012) found that sufficient availability of nutrients had positive effect on plant under metal stress by inducing several physiological processes. The processes included antioxidant activation to maintain the redox status of plant cell, removal of reactive oxygen species (ROS), and mitigation of metal-induced stress by which functionality of photosynthetic system could be maintained (Nazar et al. 2012). Dong et al. (2019) also investigated that addition of $\mathrm{Zn}$ improved the level of mineral elements to alleviate Cd toxicity in tall fescue (Festuca arundinacea). In addition, the individual element also has important role in photosynthesis processes. Magnesium $(\mathrm{Mg})$ is part of chlorophyll molecules that occupies in the middle of the chlorophyll molecules which binds tetra-pyrrole rings (Beale 1999). $\mathrm{Mg}$ is an essential macronutrient for the plant growth and development (Gransee \& Führs 2013) and numerous key functions in plants (Cakmak \& Yazici 2010). $\mathrm{Mg}$ is a cofactor and allosteric modulator for more than 300 enzymes, including carboxylases, phosphatases, kinases, RNA polymerases, and ATPases (Farhat at al. 2016). Furthermore, some researchers found that application of $\mathrm{Mg}$ in the root as well as through the leaves apparently improved chlorophyll pigments (Kováčik et al. 2014).

Other elements also important in physiological processes, such as Iron $(\mathrm{Fe})$ which is a trace element required to produce chlorophyll from its precursor 5-aminolevulinic acid (ALA), therefore, iron deficiency is a serious physiological disorder, prevalently on calcareous soil (Santos et al. 2015). Application of Fe have been reported able to improve chlorophyll content, for example in grapevine applied with Fe derived from blood bovine (Tessarin et al. 2013) and in Citrus maxima applied with foliar spray of iron oxide nanoparticles at $50 \mathrm{mg} / \mathrm{L}$ (Hu et al. 2017). The similar pattern also found in watermelon treated with iron oxide nanoparticles, where application with $20 \mathrm{mg} / \mathrm{L}$ improved chlorophyll and growth, but at the concentration higher than $50 \mathrm{mg} / \mathrm{L}$ it induced oxidative stress (Wang et al. 2015). In this experiment, therefore, higher Fe content in the tailings may be beneficial for the plant grown under very high calcium content (Table 1) as is the case of calcareous soil (Santos et al. 2015). Under metal stress condition, Fe stabilizes complex proteins and provide stability to chloroplast under Cd stress in Brassica juncea (Qureshi et al. 2010) and protects photosynthetic tissues in Lupinus albus (Zornoza et al. 2010).

\section{PLANTS GROWTH MEASUREMENT}

The treatment of gold mine tailings for 6 weeks did not significantly $(\mathrm{P}>0.05)$ affect Philippine Tung growth and morphology. There was no substantial symptom of toxicity such as leaf chlorosis or necrosis that was observed from the plants treated with gold mine tailing up to $100 \%$. Approximately only $10 \%$ of the total population underwent senescence after 6 weeks, which was spread out in all the treatments, not subject to the specific treatments, suggesting that in general these plants had good resilience to the tailing treatment. The survival of Philippine Tung under $100 \%$ gold mine tailings is good indication of tolerance, because most of the study usually use only 30 $50 \%$ of the tailings such as in several grasses (Muddarisna \& Kristayanti 2015). After 6 weeks, Philippine Tung roots had also developed and spread out very well covering all part of the media including the treatment contained 100\% of tailings (Figure 4).

The analysis of roots and shoot dry weight carried out after 6 weeks of treatment suggested that the treatment 
of gold mine tailings up to $100 \%$ significantly $(\mathrm{P}<0.05)$ increased plant growth, indicated by both roots as well as shoot dry weight of the plants (Figures $5 \& 6$ ). The treatment with the tailings up to $100 \%$ increased the average of root dry weight up to $70 \%$ in which the increase followed the pattern of curve of $\mathrm{Y}=0.54 \ln (\mathrm{x})+0.74$ $(\mathrm{R} 2=0.98)$ (Figure 5). The Harapan provenance (HR) had the lowest root dry weight among the five varieties of Philippine Tung, while Kermindo 2 (D2) showed the highest value of root dry weight followed by Kemiri Minyak 1 (M1) (Figure 5).

In line with the roots, the canopy (shoot) dry weight which was a combination of stems and leaves also increased significantly $(\mathrm{P}<0.05)$ in response to the treatment with gold mine tailings for 6 weeks (Figure 6). The maximum increase of canopy dry weight was even higher than that of the roots by which the treatment of tailings $100 \%$ caused the increase of canopy dry weight up to $90 \%$ compared to the control plant. The increase of shoot growth in response to gold mine tailings followed the pattern of the curve of $\mathrm{Y}=0.11 \mathrm{X} 2+0.25 \mathrm{X}+1.58(\mathrm{R} 2$ $=0.9852$ ) (Figure 5).

The increase of growth in response to gold mine tailing treatment was in line with photosynthesis improvement (Figure 3). To quantify relationship between photosynthetic rate and plant growth, the regression of both parameters was analyzed (Figure 7). The graph showed that photosynthesis rate has highly correlation to roots as well as shoot growth. The increase of photosynthesis of plants under higher tailing concentration caused the increase of plant growth, which suggests that Philippine Tung plant is resistance to gold mine tailings. This result is consistent with Nazar et al. (2012) who also found that higher mineral nutrition improved photosynthesis of plant exposed to $\mathrm{Cd}$ contaminant which resulted in the increase of plant dry mass, growth and yield. Higher increase of plant growth also demonstrated the capacity of the plant to act in phytoremediation. Some researcher also uses growth rate as an important indicator for plant that will be used in phytoremediation program (Muddarisna \& Kristayanti 2015). Higher total dry weight illustrated higher total accumulation of metal in the tissues that is important for phytoremediation. Philippine Tung has been proven to survive well in some post-mined land such as tin, bauxite and cement mining (Pranowo \& Herman 2015). Since this species was proven be able to absorb and accumulate $\mathrm{Pb}$ to the leaves based on qualitative histochemical analysis (Hilmi et al. 2018), this experiment considered that Philippine Tung is resistant to gold mine land and have good potential for phytoremediation process in gold mining area.

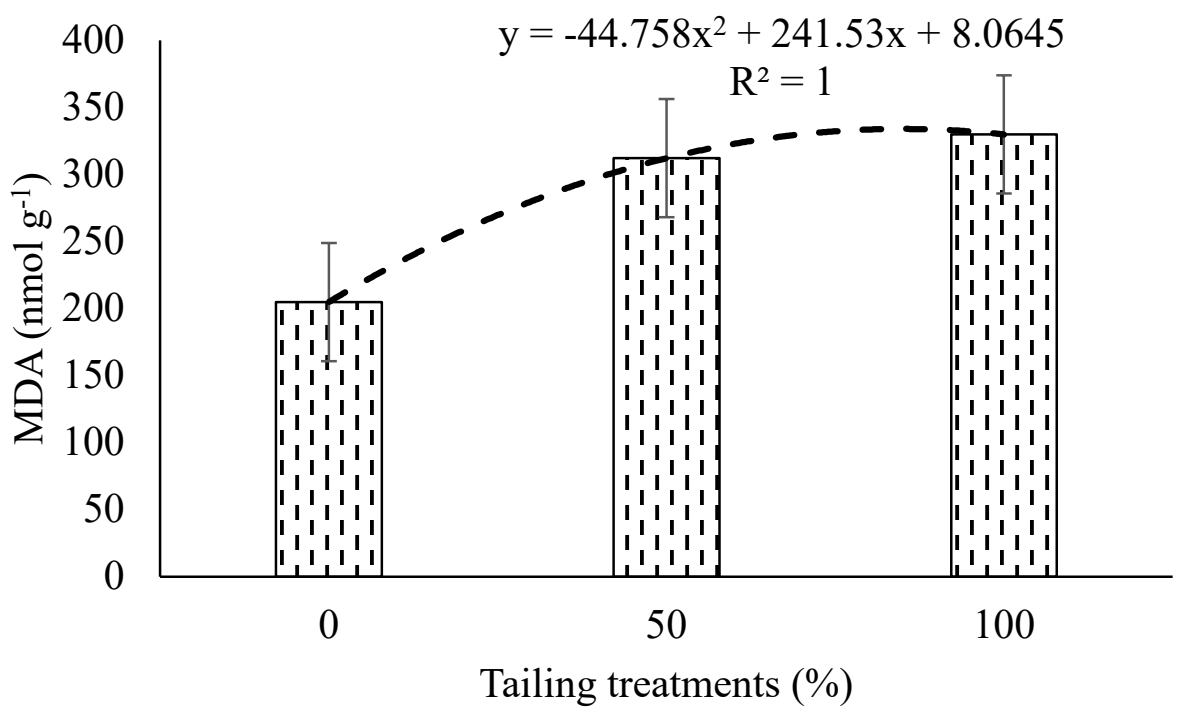

FIGURE 1. Increased MDA content of Kemiri Sunan leaves in response to treatment with solid tailings 50 and $100 \%$. Error bars represent \pm SE of Duncan's test, $\mathrm{p}<0.05$ 


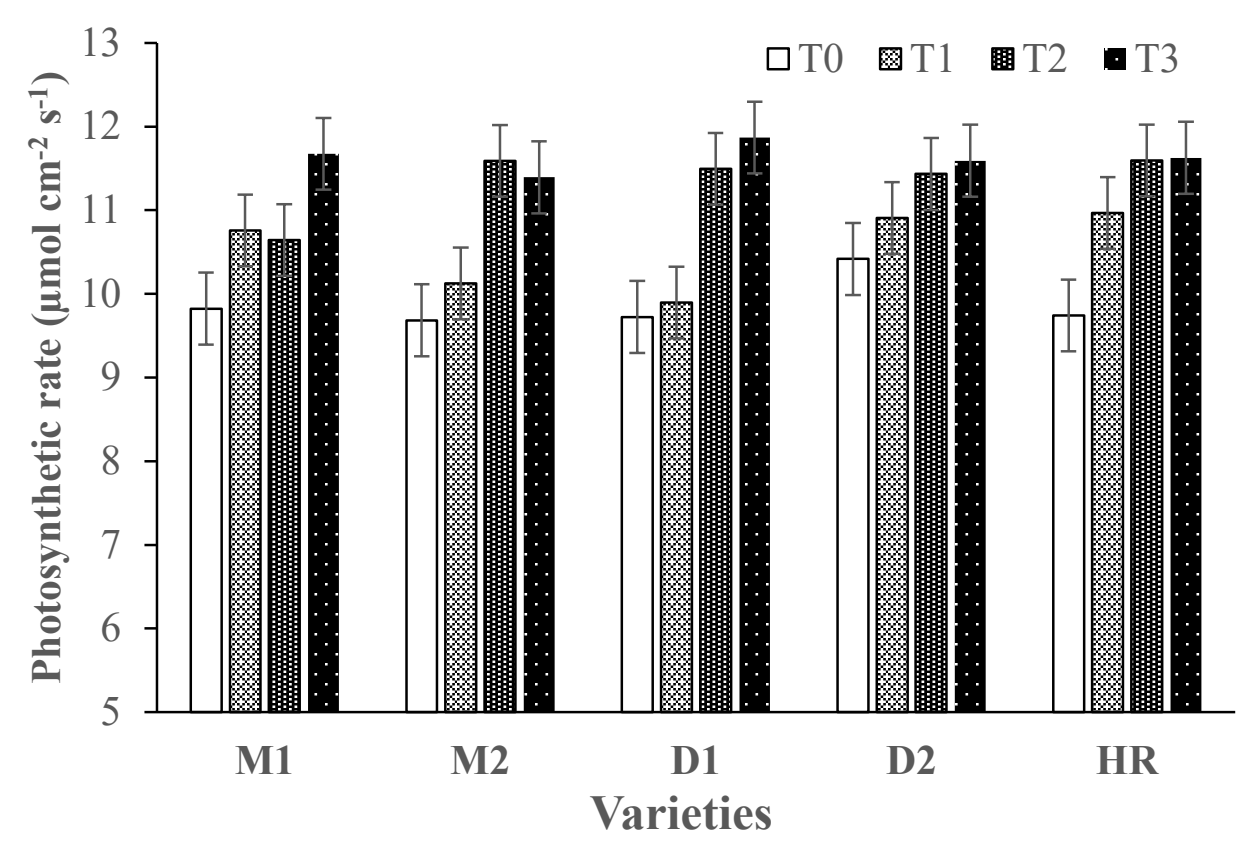

FIGURE 2. The photosynthetic rate of Kemiri sunan varieties treated with tailings with the concentration of 0 (T0), 25 (T1), 50 (T2) and 100\% (T3) in the media (M1: Kemiri Minyak 1, M2: Kemiri Minyak 2, D1: Kermindo 1, D2: Kerrmindo 2 and HR: Harapan line). Error bars represent $\pm \mathrm{SE}$ of Duncan's test, $\mathrm{p}<0.05$
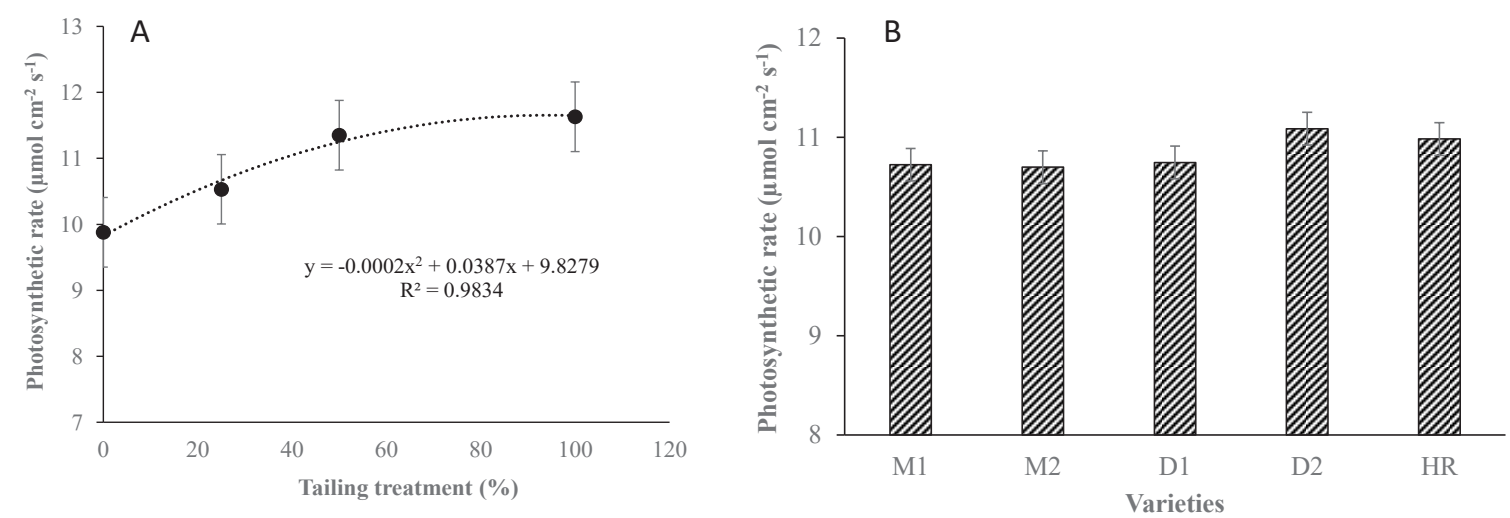

FIGURE 3. The average of photosynthetic rate of five varieties in response to gold-mine tailings with the concentration of $0,25,50$, and $100 \%$ (A), and The average of photosynthetic rate of each Kemiri Sunan varieties (B), (M1: Kemiri Minyak 1, M2: Kemiri Minyak 2, D1: Kermindo 1, D2: Kerrmindo 2 and HR: Harapan line). Error bars represent \pm SE of Duncan's test, $p<0.05$ 

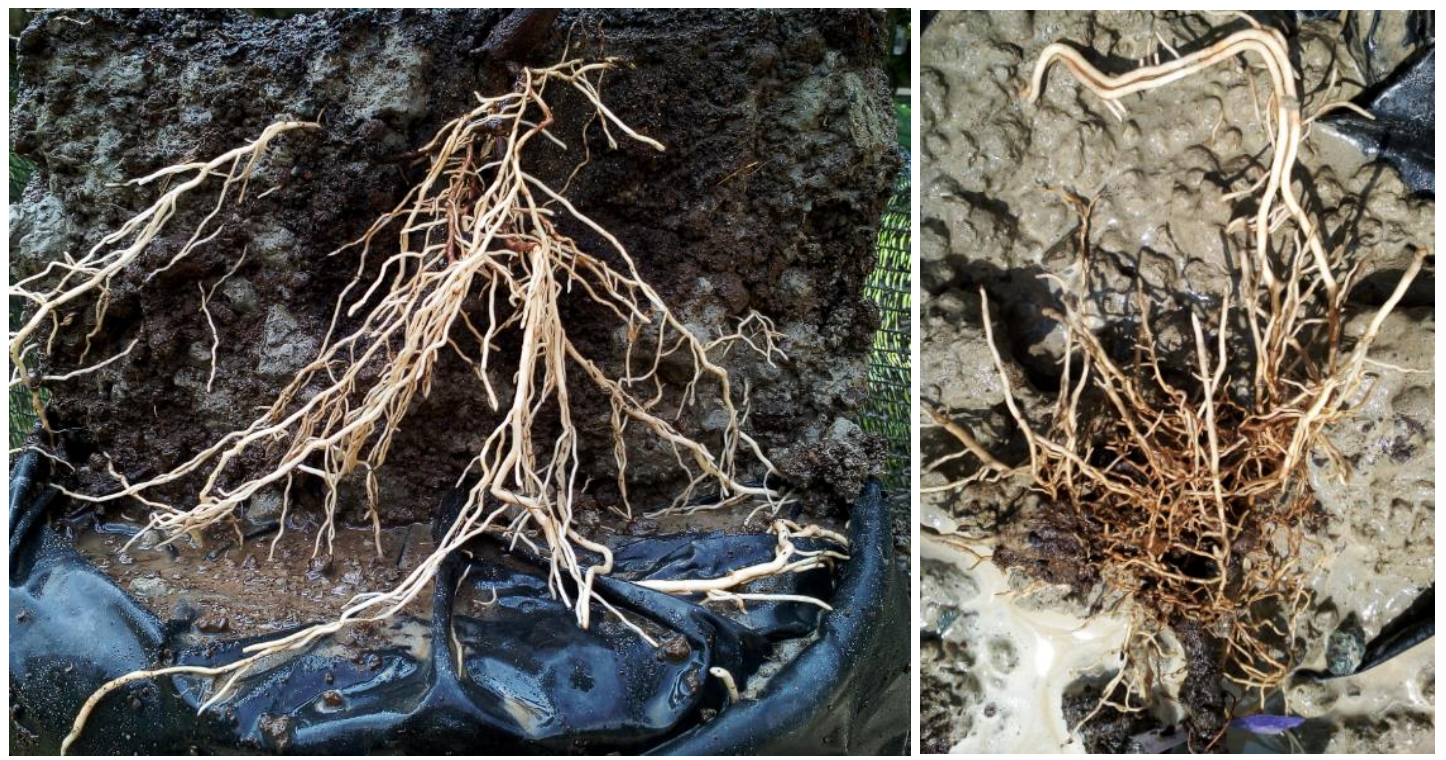

FIGURE 4. Kemiri Sunan roots penetrated and spread out within the media treated with gold mine tailings of 50\%

(left) and $100 \%$ (right) after 6 weeks of the treatment
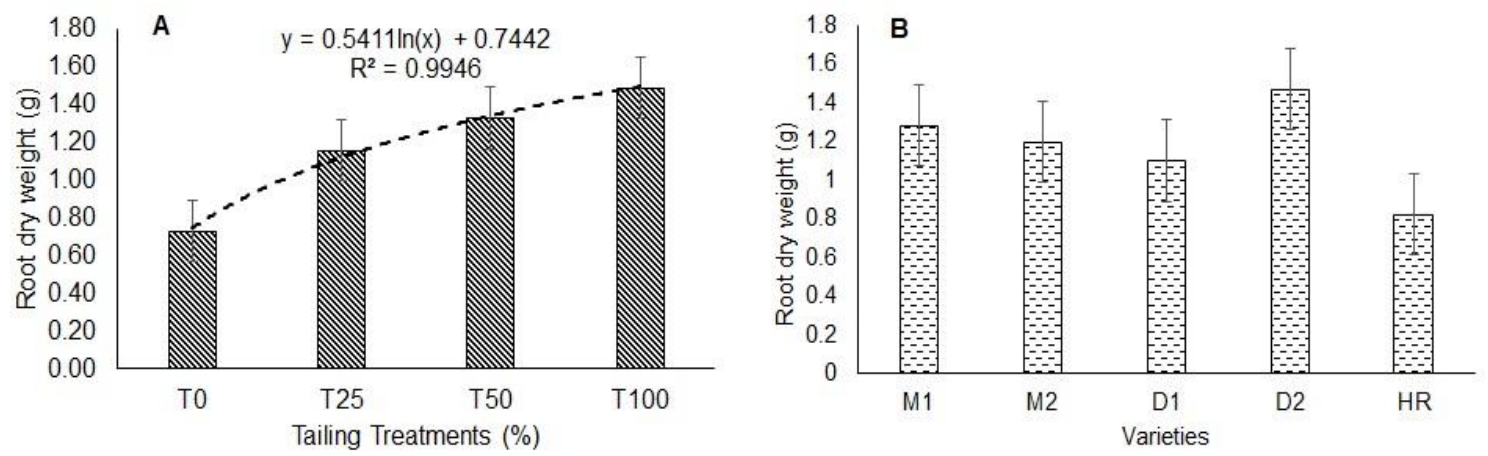

FIGURE 5. The average of root dry weight of 5 varieties of

Kemiri Sunan in response to tailing treatment for 6 weeks

(A) and the variation of root dry weight of each varieties

(B). Error bars represent \pm SE of Duncan's test, $\mathrm{p}<0.05$
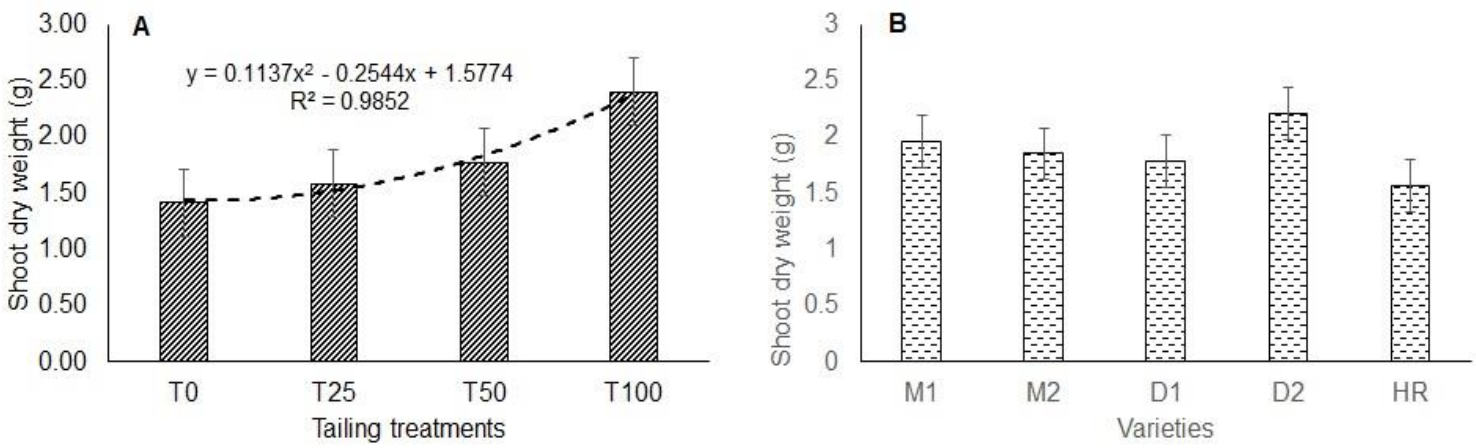

FIGURE 6. The average of shoot dry weight of 5 Kemiri sunan varieties in response to the treatment with various solid tailings for 6 weeks (left) and the variation of canopy dry weights of Kemiri sunan varieties (right). Error bars represent \pm SE of Duncan's test, $\mathrm{p}<0.05$ 


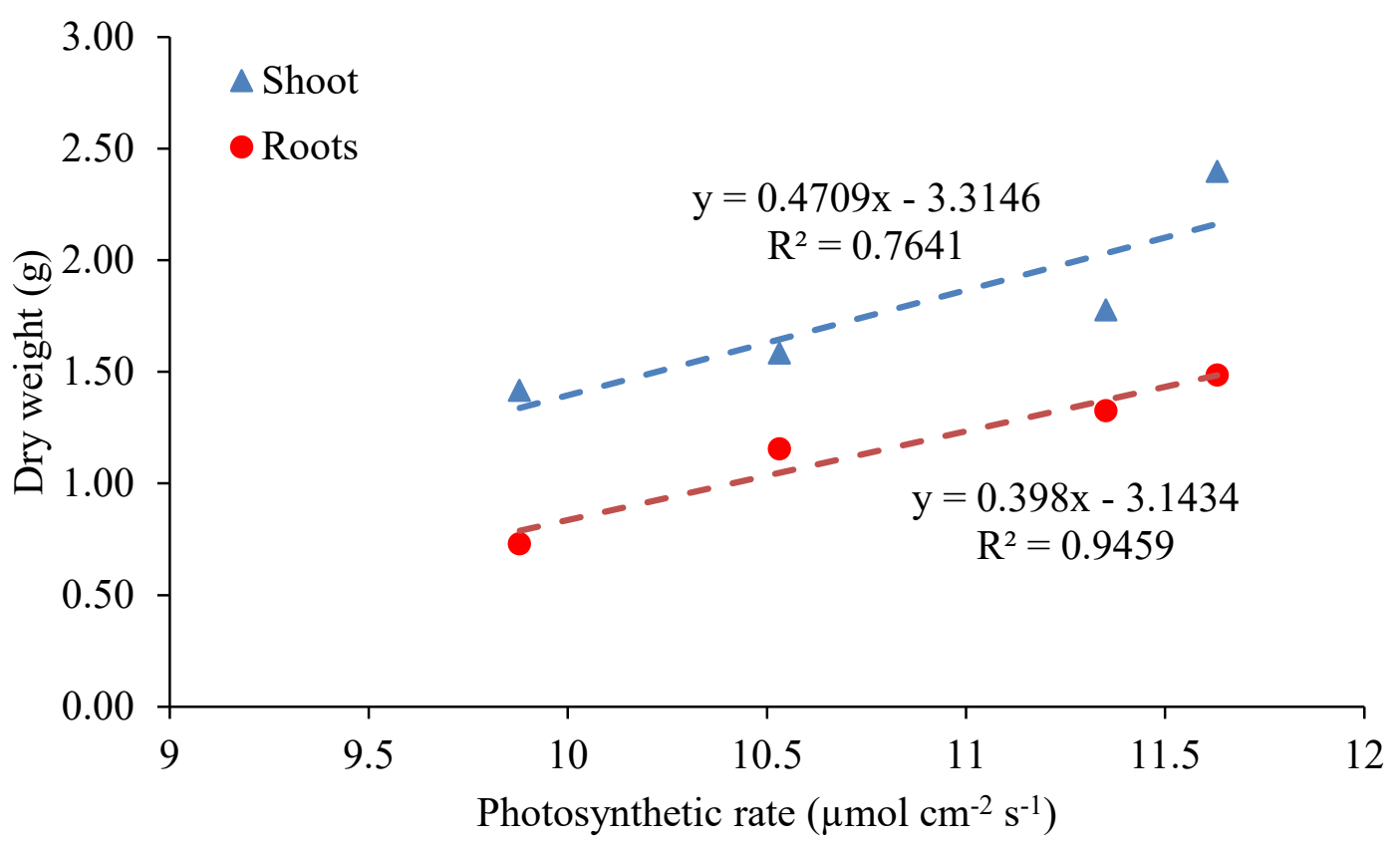

FIGURE 7. Regression analysis of photosynthetic rate and growth of Kemiri Sunan represented by roots dry weight $(\bullet)$ and shoot dry weight $(\boldsymbol{\Delta})$ of 5 varieties grown for 6 weeks with different gold mine tailings concentration

\section{CONCLUSION}

Five varieties of biodiesel producer plants (Reutealis trisperma [Blanco] Airy Shaw) treated with gold-mine tailings until $100 \%$ were able to sustain and grow well for 6 weeks in the greenhouse experiment. Gold-mine tailings treatment increased malondildehyde (MDA) content up to $61 \%$. After 6 weeks, R. trisperma treated with gold-mine tailing had higher photosynthetic rate (up to $17 \%$ ) than that of the control (untreated) plants, which resulted in the improvement of root and shoot growth up to 70 and $90 \%$, respectively. Higher content of $\mathrm{Ca}, \mathrm{Mg}$, $\mathrm{Fe}, \mathrm{Zn}$, and $\mathrm{Mn}$ in the tailing was probably the cause of the positive effect of the tailing treatment to these plants. Based on growth and photosynthesis sustainability during the treatment, $R$. trisperma plants are tolerant to gold-mine tailings.

\section{ACKNOWLEDGEMENTS}

The authors would like to express their appreciation to the Ministry of Research and Higher Education, Republic of Indonesia for the support of the sponsors with Project No 4142/IT3.L1/PN/2019. We also thank the Gold Mine National Industry, Aneka Tambang Incorporation, (PT ANTAM) UBPE Pongkor, Bogor, Indonesia which provide tailing materials to support this research.

\section{REFERENCES}

Ali, H., Khan, E. \& Sajad, M.A. 2013. Phytoremediation of heavy metals - concepts and applications. Chemosphere 91(7): 869-881.

Allakhverdiev, S.I., Kreslavski, V.D., Klimov, V.V., Los, D.A., Carpentier, R. \& Mohanty, P. 2008. Heat stress: An overview of molecular responses in photosynthesis. Photosynthesis Research 98(1-3): 541-550.

Apel, K. \& Hirt, H. 2004. Reactive oxygen species: Metabolism, oxidative stress, and signal transduction. Annual Review of Plant Biology 55: 373-399.

Arifin, Y.I., Sakakibara, M. \& Sera, K. 2015. Impacts of artisanal and small-scale gold mining (ASGM) on environment and human health of Gorontalo Utara Regency, Gorontalo Province, Indonesia. Geosciences 5(2): 160-176.

ATSDR 2003. Agency for Toxic Substances and Disease Registry. U.S. Department of Health \& Human Services. Accessed on 10 November 2018.

Beale, S.I. 1999. Enzymes of chlorophyll biosynthesis. Photosynthesis Research 60(1): 43-73.

Cakmak, I. \& Yazici, A.M. 2010. Magnesium: A forgotten element in crop production. Better Crops 94(2): 23-25.

Chaffai, R. \& Koyama, H. 2011. Heavy metal tolerance in Arabidopsis thaliana. Advances in Botanical Research 60: $1-49$.

Choppala, G., Saifullah, Bolan, N., Bibi, S., Iqbal, M., Rengel, Z., Kunhikrishnan, A., Ashwath, N. \& Ok, Y.S. 2014. Cellular 
mechanisms in higher plants governing tolerance to cadmium toxicity. Critical Reviews in Plant Sciences 33(5): 374-391.

Dong, Q., Hu, S., Fei, L., Liu, L. \& Wang, Z. 2019. Interaction between $\mathrm{Cd}$ and $\mathrm{Zn}$ on metal accumulation, translocation and mineral nutrition in tall fescue (Festuca arundinacea). International Journal of Molecular Sciences 20(13): 3332.

Ekmekçi, Y., Tanyolac, D. \& Ayhan, B. 2008. Effects of cadmium on antioxidant enzyme and photosynthetic activities in leaves of two maize cultivars. Journal of Plant Physiology 165(6): 600-611.

Erakhrumen, A.A. \& Agbontalor, A. 2007. Phytoremediation: An environmentally sound technology for pollution prevention, control and remediation in developing countries. Educational Research and Review 2(7): 151-156.

Farhat, N., Elkhouni, A., Zorrig, W., Smaoui, A., Abdelly, C. \& Rabhi, M. 2016. Effects of magnesium deficiency on photosynthesis and carbohydrate partitioning. Acta Physiologiae Plantarum 38(6): 145.

Ghosh, M. \& Singh, S.P. 2005. A review on phytoremediation of heavy metals and utilization of it's by products. Asian Journal on Energy and Environment 6(4): 18.

Gransee, A. \& Führs, H. 2013. Magnesium mobility in soils as a challenge for soil and plant analysis, magnesium fertilization and root uptake under adverse growth conditions. Plant and Soil 368(1-2): 5-21.

Guala, S.D., Vega, F.A. \& Covelo, E.F. 2010. The dynamics of heavy metals in plant-soil interactions. Ecological Modelling 221(8): 1148-1152.

Hamim, H., Hilmi, M., Pranowo, D., Saprudin, D. \& Setyaningsih, L. 2017a. Morpho-physiological changes of biodiesel producer plants Reutealis trisperma (Blanco) in response to gold-mining wastewater. Pakistan Journal of Biological Science: PJBS 20(9): 423-435.

Hamim, H., Violita, V., Triadiati, T. \& Miftahudin, M. 2017b. Oxidative stress and photosynthesis reduction of cultivated (Glycine max L.) and wild soybean (G. tomentella L.) exposed to drought and paraquat. Asian Journal of Plant Sciences 16(2): 65-77.

Hamim, H., Banon, S. \& Dorly, D. 2016. Comparison of physiological and anatomical changes of $\mathrm{C} 3$ (Oryza sativa [L.]) and C4 (Echinochloa crusgalli [L.]) leaves in response to drought stress. IOP Conference Series: Earth and Environmental Science 31: 012040.

Herman, M. \& Pranowo, D. 2010. Kemiri sunan untuk konservasi tanah dan air. Sirkuler teknologi Tanaman Rempah dan Industri. Sukabumi: Balai Penelitian Tanaman Rempah dan Aneka Tanaman Industri.

Herman, M., Syakir, M., Pranowo, D., Syaefudin \& Sumanto. 2013. Kemiri Sunan (Reutealis trisperma (Blanco) Airy Shaw) Vegetable Oil Producing Plant and Land Conservation. Jakarta: IAARD Press.

Hidayati, N., Juhaeti, T. \& Syarif, F. 2009. Mercury and cyanide contaminations in gold mine environment and possible solution of cleaning up by using phytoextraction. HAYATI Journal of Biosciences 16(3): 88-94.

Hilmi, M., Hamim, Sulistyaningsih, Y.C. \& Taufikurahman, T. 2018. Growth, histochemical and physiological responses of non-edible oil producing plant (Reutealis trisperma) to gold mine tailings. Biodiversitas Journal of Biological Diversity 19(4): 1294-1302.

Hu, J., Guo, H., Li, J., Gan, Q., Wang, Y. \& Xing, B. 2017. Comparative impacts of iron oxide nanoparticles and ferric ions on the growth of Citrus maxima. Environmental Pollution 221: 199-208.

Korte, F., Spiteller, M. \& Coulston, F. 2000. The cyanide leaching gold recovery process is a nonsustainable technology with unacceptable impacts on ecosystems and humans: The disaster in Romania. Ecotoxicology and Environmental Safety 46(3): 241-245.

Kováčik, P., Baran, A., Filová, A., Vician, M. \& Hudec, J. 2014. Content changes of assimilative pigments in leaves after fertilizer Mg-Titanit application. Acta Fytotechnica et Zootechnica 17(2): 58-64.

Maksymiec, W. 2007. Signaling responses in plants to heavy metal stress. Acta Physiologiae Plantarum 29(3): 177-185.

Muddarisna, N. \& Krisnayanti, B.D. 2015. Selection of mercury accumulator plants for gold mine tailing contaminated soils. Journal of Degraded and Mining Lands Management 2(3): 341-346.

Muddarisna, N., Krisnayanti, B.D., Utami, S.R. \& Handayanto, E. 2013. The potential of wild plants for phytoremediation of soil contaminated with mercury of gold cyanidation tailings. Journal of Environmental Science, Toxicology and Food Technology 4(1): 15-19.

Nazar, R., Iqbal, N., Masood, A., Khan, M.I.R., Syeed, S. \& Khan, N.A. 2012. Cadmium toxicity in plants and role of mineral nutrients in its alleviation. American Journal of Plant Sciences 3(10): 1476-1489.

Nazar, R., Iqbal, N., Syeed, S. \& Khan, N.A. 2011. Salicylic acid alleviates decreases in photosynthesis under salt stress by enhancing nitrogen and sulfur assimilation and antioxidant metabolism differentially in two mungbean cultivars. Journal of Plant Physiology 168(8): 807-815.

Ono, K., Yamamoto, Y., Hachiya, A. \& Matsumoto, H. 1995. Synergistic inhibition of growth by aluminum and iron of tobacco (Nicotiana tabacum L.) cells in suspension culture. Plant and Cell Physiology 36(1): 115-125.

Popova, L.P., Maslenkova, L.T., Yordanova, R.Y., Ivanova, A.P., Krantev, A.P., Szalai, G. \& Janda, T. 2009. Exogenous treatment with salicylic acid attenuates cadmium toxicity in pea seedlings. Plant Physiology and Biochemistry 47(3): 224-231.

Pranowo, D. \& Herman, M. 2015. Potensi pengembangan kemiri sunan (Reutealis trisperma (blanco) airy shaw) di lahan terdegredasi. Perspektif 14: 87-102.

Qureshi, M.I., D’Amici, G.M., Fagioni, M., Rinalducci, S. \& Zolla, L. 2010. Iron stabilizes thylakoid protein-pigment complexes in Indian mustard during Cd-phytoremediation as revealed by BN-SDS-PAGE and ESI-MS/MS. Journal of Plant Physiology 167(10): 761-770.

Santos, C.S., Roriz, M., Carvalho, S.M. \& Vasconcelos, M.W. 2015. Iron partitioning at an early growth stage impacts iron deficiency responses in soybean plants (Glycine max L.). Frontiers in Plant Science 6: 325.

Sarwar, N., Malhi, S.S., Zia, M.H., Naeem, A., Bibi, S. \& Farid, G. 2010. Role of mineral nutrition in minimizing cadmium accumulation by plants. Journal of the Science of Food and Agriculture 90(6): 925-937.

Sarwar, N., Imran, M., Shaheen, M.R., Ishaque, W., Kamran, M.A., Matloob, A., Rehim, A. \& Hussain, S. 2017. Phytoremediation strategies for soils contaminated with heavy metals: Modifications and future perspectives. Chemosphere 171: 710-721. 
Savicka, M. \& Škute, N. 2010. Effects of high temperature on malondialdehyde content, superoxide production and growth changes in wheat seedlings (Triticum aestivum L.). Ekologija 56(1): 26-33.

Seth, C.S. 2012. A review on mechanisms of plant tolerance and role of transgenic plants in environmental clean-up. The Botanical Review 78(1): 32-62.

Seth, C.S., Chaturvedi, P.K. \& Misra, V. 2007. Toxic effect of arsenate and cadmium alone and in combination on giant duckweed (Spirodela polyrrhiza L.) in response to its accumulation. Environmental Toxicology: An International Journal 22(6): 539-549.

Setyaningsih, L., Setiadi, Y., Budi, S.W. \& Sopandie, D. 2017. Lead accumulation by jabon seedling (Anthocephalus cadamba) on tailing media with application of compost and arbuscular mycorrhizal fungi. IOP Conference Series: Earth and Environmental Science 58(1): 012053.

Taiz, L. \& Zeiger, E. 2010. Plant Physiology. Third Edition. Sunderland: Sinauer Associates.

Tessarin, P., Ingrosso, E., Rombolà, A.D., Boliani, A.C., Covarrubias, J.I. \& Yunta, F. 2012. Improvement of grapevine iron nutrition by a bovine blood-derived compound. VII International Symposium on Mineral Nutrition of Fruit Crops 984: 335-338.

Vamerali, T., Bandiera, M. \& Mosca, G. 2010. Field crops for phytoremediation of metal-contaminated land. A review. Environmental Chemistry Letters 8(1): 1-17.

Wang, M., Liu, X., Hu, J., Li, J. \& Huang, J. 2015. Nano-ferric oxide promotes watermelon growth. Journal of Biomaterials and Nanobiotechnology 6(03): 160-167.

Xu, J., Yin, H. \& Li, X. 2009. Protective effects of proline against cadmium toxicity in micropropagated hyperaccumulator, Solanum nigrum L. Plant Cell Reports 28(2): 325-333.

Zornoza, P., Sánchez-Pardo, B. \& Carpena, R.O. 2010. Interaction and accumulation of manganese and cadmium in the manganese accumulator Lupinus albus. Journal of Plant Physiology 167(13): 1027-1032.
Hamim Hamim*

Department of Biology

Faculty of Mathematics and Natural Sciences

IPB University

Jl. Agathis, Kampus IPB Darmaga, Bogor

Indonesia

Dibyo Pranowo

Research Institute for Industrial and Refreshing Crops (Balittri) Indonesian Agency for Agricultural Research and Development Ministry of Agriculture of Republic of Indonesia

Pakuwon, Sukabumi, West Java

Indonesia

Luluk Setyaningsih

Faculty of Forestry

University of Nusa Bangsa, Bogor

Indonesia

Muhammad Hilmi

School of Vocation IPB University, Bogor

Indonesia

\section{Deden Saprudin}

Department of Chemistry

Faculty of mathematics and Natural Sciences

IPB University, Bogor

Indonesia

*Corresponding author; email: hamim@apps.ipb.ac.id

Received: 15 January 2020

Accepted: 7 May 2020 